\title{
Aortic valve replacement using bovine pericardial bioprostheses: 12 years of experience
}

Substituição valvar aórtica por bioprótese de pericárdio bovino: 12 anos de experiência

Domingo M. BRAILE, João Carlos LEAL, Moacir Fernandes GODOY, Maria Christiane Valéria BRAILE, Alfredo de PAULA NETO

RBCCV 44205-640

\section{Abstract}

Objectives: The present study is aimed at evaluating the long-term outcomes (up to 12 years of follow-up) of patients undergoing aortic valve replacement using bovine pericardial prostheses.

Method: From March 1992 to January 2003, 287 patients underwent aortic valve replacement as a single procedure, using bovine pericardial prostheses. Of these, $189(65.9 \%)$ were males. Ages ranged from 15 to 82 years with a mean and standard deviation of $53.6 \pm 15.1$ years and median of 56 years. The diameters of the bioprostheses ranged from 21 to $29 \mathrm{~mm}$ of which $23 \mathrm{~mm}(105$ cases, $36.6 \%)$ and $25 \mathrm{~mm}(105$ cases, $36.6 \%$ ) were the most prevalent sizes. Only in 1 patient was a 29-mm prosthesis implanted. The assessed variables were late overall survival, comparative survival of patients $<70$ years and $\geq 70$ years of age and the percentage of patients free from reoperations due to primary valve failure. Statistical analysis was performed with the aid of actuarial curves (Kaplan-Meier).
Results: The overall actuarial survival at the end of 12 years was $91.7 \pm 2.2 \%$. Separate analysis of patients $<70$ years (Group $A=252$ patients) and $\geq 70$ years (Group $B=35$ patients) showed the overall survival in Group $A$ was $94.7 \pm$ $\mathbf{1 . 7 \%}$ and $58.1 \pm \mathbf{1 7 . 2 \%}$ in Group $B$ (Logrank test $P=0.0005$; $1.7 \%$ and $58.1 \pm 17.2 \%$ in Group $B$ (Logrank test $P=0.0005$;
Hazard Ratio $0.2095 \%$ CI 0.01 to 0.29 ). The rate free from reoperation due to primary valve failure was $96.1 \pm 2.0 \%$ at the end of 12 years. The 4 patients with implantation failure were in Group $A$ and had a mean age of 49.7 years.

Conclusions: the use of bovine pericardial prostheses in patients with aortic valve disease provides an excellent survival rate over 12 years of follow-up. Patients with 70 years and over had a significantly lower survival, but dysfunctions were only observed in the younger group of patients.

Descriptors: Bioprosthesis, Aortic valve, Survival, Clinical Evolution.

Institution: Braile Cardiocirurgia and Medical School of São José do Rio Preto, Brazil (FAMERP)

Correspondence address: Domingo M. Braile

Av. Juscelino Kubitschek 1505 - 15091-4510 - São José do Rio Preto - SP

Phone: 17-2107004 - Fax: 17-2107030

E-mail: domingo@braile.com.br

Article received on May, 2003 Article accepted on August, 2003

The author informed of the existence of conflict of interest 


\section{Resumo}

Objetivos: O presente estudo visa avaliar a evolução a longo prazo (até 12 anos de seguimento) de pacientes submetidos a substituição valvar aórtica por bioprótese de pericárdio bovino.

Método: De marco 1992 a janeiro 2003, 287 pacientes foram submetidos a substituição valvar aórtica como procedimento isolado, utilizando-se bioprótese de pericárdio bovino. Destes, $189(65,9 \%)$ eram do sexo masculino. As idades variaram de 15 a 82 anos com média e desvio padrão de $53,6 \pm 15,1$ anos e mediana de 56 anos. $O$ diâmetro das biopróteses variou de 21 a $29 \mathrm{~mm}$, sendo que os mais prevalentes foram o de $23 \mathrm{~mm}$ (105 casos; 36,6\%) e o de 25 mm (outros 105 casos; 36,6\%) Apenas um paciente recebeu prótese com diâmetro de 29 mm. Os eventos estudados foram sobrevivência tardia global, sobrevivência comparativa em pacientes abaixo de 70 anos e com 70 anos ou mais e porcentagem livre de reintervenções por qualquer causa de disfunção primária da bioprótese. A análise dos resultados foi feita com auxílio de curva atuarial Kaplan-Meier.

\section{INTRODUCTION}

In the last decades, in an attempt to find a valvular prosthesis with the closest possible hemodynamic performance to native valves, new alternatives emerged aiming at reducing primary failures related to prostheses, to diminish the left ventricular mass and increase the survival rate [1-4].

Knowledge that the aortic valve could be replaced originated in 1952, when Charles Hufnagel implanted a ballvalve prosthesis in the ascending aorta of a patient suffering from severe aortic failure [5]. From then on a great number of valvular prostheses have been widely used with several new models appearing on the market [6-8]

Studies using bioprostheses (autograft, homograft and heterograft) gave promising results, in relation to death and the quality of life of patients $[9,10]$. The bioprostheses of heterologous tissue stood out after encountering difficulties in collecting homologous tissues (fascia lata and dura mater) and the use of low concentration fixers to preserve the tissues $[11,12]$. More recently, some heart surgeons demonstrated an interest in stentless bioprostheses due to their favorable hemodynamic characteristics [13,14]. However, the majority of medium- and long-term results did not confirm this advantage [15]. Braile et al. in the 1970s divulged a vast experience with bovine pericardial valves preserved in glutaraldehyde $[16,17]$.

The aim of this study was to assess the long-term evolution (up to 12 years of follow-up) of patients submitted to aortic valve replacement using bovine pericardial prostheses.

\section{METHOD}

In the period from March 1992 to January 2003, 287 patients underwent aortic valvar replacement, as a primary isolated
Resultados: A taxa atuarial de sobrevivência global ao final de 12 anos foi de $91,7 \pm 2,2 \%$. A separação em grupos abaixo de 70 anos (Grupo $A=252$ pts) e 70 anos ou mais (Grupo $B=35$ pts) mostrou que, no grupo $A$, a sobrevivência global foi de $\mathbf{9 4 , 7} \pm 1,7 \%$, enquanto que no grupo $B$ foi de $58,1 \pm 17,2 \%$ (Logrank test p= 0,0005; Hazard Ratio 0,20 IC95\% 0,01 a $0,29)$. A taxa livre de reintervenções por causa primária da 0,29). A taxa livre de reintervenções por causa primária da
bioprótese foi de $96,1 \pm 2,0 \%$, ao final de 12 anos. Os quatro pacientes que apresentaram disfunção pertenciam ao grupo A, com média de idade de 49,7 anos.

Conclusões: $\mathbf{O}$ uso da bioprótese de pericárdio bovino em portador de doença valvular aórtica proporciona excelente taxa de sobrevivência após 12 anos de seguimento. Pacientes com idade igual ou superior a 70 anos apresentaram sobrevivência significativamente menor, mas as disfunções ocorreram exclusivamente no grupo de menor idade.

Descritores: Bioprótese. Prótese das valvas cardíacas, estatística \& dados numéricos. Valva aórtica, cirurgia.

procedure, utilizing bovine pericardial bioprostheses (BIOPRO). Of these cases 189 (65.9\%) were male. The ages ranged from 15 to 82 years old with a mean and standard deviation of $53.6 \pm 15.1$ years and a median of 56 years. The diameter of the bioprostheses varied from 21 to $29 \mathrm{~mm}$ with 23 $\mathrm{mm}$ and $25 \mathrm{~mm}$ being the most commonly used (105 cases $36.6 \%$ using $23 \mathrm{~mm}$ and another 105 cases $36.6 \%$ using 25 $\mathrm{mm}$ ). Only one patient received a prosthesis of $29 \mathrm{~mm}$.

The operative procedures performed were elective and conventional. The myocardial protection employed was tepid, continuous low-volume anterograde/retrograde blood [18].

The studied events were global late survival rate, comparative survival rate between under-70-year-old and over-70-year-old patients and the re-intervention free percentage, that is, free of any primary bioprosthetic dysfunction.

Analysis of the results was made using Kaplan-Meier type actuarial curves.

\section{RESULTS}

No low output syndrome or death occurred during hospitalization. The patients were extubated in the ICU and released to the ward after 48 hours. No left ventricular dysfunction was documented by echocardiogram after the global hospital stay of 7 days.

The actuarial global survival rate at the end of 12 years was $91.7 \pm 2.2 \%$ (Figure 1 ). The patients were split into two groups of under 70-year-olds (Group $\mathrm{A}=252$ patients) and over 70-year-olds (Group B $=35$ patients). Analysis of these groups demonstrated that, in group A the global survival rate was $94.7 \pm 1.7 \%$ whilst in Group B it was $58.1 \pm 17.2 \%$ (Logrank test p-value $=0.0005$; Hazard ratio 0.20 CI 95\% 0.01 
to 0.29 ) (Figure 2). The re-intervention free rate for any cause related to primary bioprosthetic dysfunction was $96.1 \pm 2.0$ at the end of 12 years (Figure 3). The four patients who presented with dysfunction belonged to Group A, with an average age of 49.7 years.

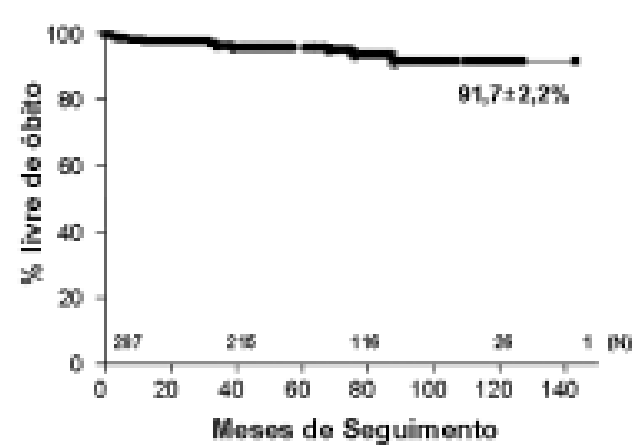

Fig. 1 - Actuarial global survival curve (Kaplan-Meier) of bovine pericardial aortic valvar bioprostheses



Fig 2. Actuarial survival curve (Kaplan-Meier) of postimplantation of bovine pericardial aortic valvar bioprostheses grouped by age

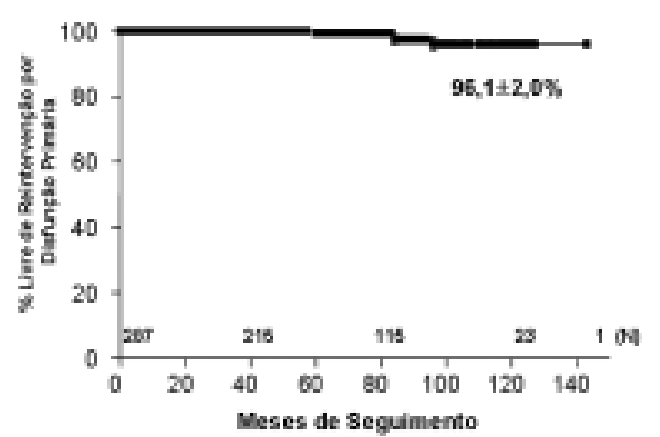

Fig. 3 - Actuarial curve of the bovine pericardial bioprosthesis (BIOPRO) in the aortic position free of primary failure

\section{DISCUSSION}

The improved techniques for the production of prostheses, the trans-operative period with a better control of myocardial protection and cardiopulmonary bypass and the post-operative period with better drugs and more sophisticated propedeutic methods have all enabled a longer life and a better quality of life for patients. However, there is still a challenge to produce an 'ideal prosthesis'. The complications inherent to the presence of prostheses are real and depend on specific aspects of each individual patient.

Evidence points to the long-term advantages of bioprostheses $[19,20]$. In respect to bioprostheses, two basic aspects should be considered: the type of material utilized and the use of stented or stentless prostheses. Several publications have been produced approaching the hemodynamic behavior of prostheses in respect to these aspects $[21,22]$. Bovine pericardial prostheses possess excellent hemodynamic function [23], however the structural deterioration is a weak point, thus putting its durability into question.

We believe that the resistance and the survival rate of patients are highly relevant results dependent on the hemodynamic performance of the prostheses. GLOWER et al. in 1994, published an evaluation of 960 patients who underwent aortic valve replacement using porcine bioprostheses and confirmed that $76 \% \pm 3 \%$ of the patients were free of reoperations after 10 post-operative years [24]. One year after, COSGROVE et al. [25](1995) published their results with bovine pericardial prostheses with low structural deterioration over ten years of follow-up. Recently, VITALE et al (2003) demonstrated reduced mortality and morbidity rates with Perimount bovine pericardial bioprostheses over a 12-year period [26].

Cohen et al. in 2002, demonstrated there was no hemodynamic advantage using stentless in comparison to stented prostheses in 12 months of follow-up [15]. This instigated our study.

The BIOPRO bioprosthesis utilized to replace the aortic valve gave excellent results over up to 12 years of follow up, similar to the results on the Perimount bovine pericardial prostheses that is considered the gold standard. The survival rates and primary dysfunctions related to the bioprostheses certainly demonstrate advantages for the patient.

\section{CONCLUSION}

The use of BIOPRO bovine pericardial bioprostheses in aortic valve disease patients gives an excellent survival rate over a 12-year follow-up period. Patients with ages greater than or equal to 70 years present with a significantly lower survival rate, but dysfunctions exclusively occurred in patients in the lower age range. 


\section{BIBLIOGRAPHIC REFERENCES}

1. David TE, Feindel CM, Scully HE, Bos J, Rakowski H. Aortic valve replacement with stentless porcine aortic valves: a tenyear experience. J Heart Valve Dis 1998; 7: 250-4.

2. De Paulis R, Sommariva L, Colagrande L, De Matteis GM, Fratini S, Tomai $\mathrm{F}$ et al. Regression of left ventricular hypertrophy after aortic valve replacement for aortic stenosis with different valve substitutes. J Thorac Cardiovasc Surg 1998;116: 590-8.

3. Khan SS, Trento A, DeRobertis M, Kass RM, Sandhu M, Czer LS et al. Twenty-year comparison of tissue and mechanical valve replacement. J Thorac Cardiovasc Surg $2001 ; 122 \cdot 2 \cdot 257-69$.

4. Jamieson WR, Janusz MT, MacNab J, Henderson C. Hemodynamic comparison of second-and third-generation stented bioprostheses in aortic valve replacement. Ann Thorac Surg 2001;71 (5 Suppl):S282-4.

5. Hufnagel CA, Harwey WP. The surgical correction of aortic insufficiency. Bull Georgetown Med Cent 1953; 6:60.

6. Starr A, Edwards ML. Mitral replacement: clinical experience with a ball valve prosthesis. Ann Surg 1961; 15:726-40.

7. Harken DE, SoroffHS, Taylor WJ. Partial and complete prosthesis in aortic insufficiency. J Thorac Cardiovasc Surg 1960; 40:744.

8. Felipozzi HJ. Transplante de válvulas homólogas no tratamento cirúrgico das lesões da válvula aórtica. In: XXIII Congresso Brasileiro de Cardiologia; 1967; São Paulo. Anais. São Paulo: Sociedade Brasileira de Cardiologia; 1967. p. 37.

9. Murray G. Homologous aortic valve segment transplants as surgical treatment for aortic and mitral insufficiency. Angiology $1956 ; 7: 466-76$

10. Ross D. Allograft root replacement for prosthetic endocarditis J Card Surg 1990; 5:68-72.

11. Senning A - Aortic valve replacement with fascia-lata. Acta Chir Scand 1966; 356B:17-20.

12. Puig LB, Verginelli G, Bellotti G, Kawabe L, Frack CC, Pilegg $\mathrm{F}$ et al. Homologous dura mater cardiac valve: preliminary study of 30 cases. J Thorac Cardiovasc Surg 1972; 64:154-60.

13. David TE. Aortic valve replacement with stentless porcine bioprostheses. J Card Surg 1998; 13:344-51.

14. Silberman S, Shaheen J, Merin O, Fink D, Shapira N, LiviatanStrauss $\mathrm{N}$ et al. Exercise hemodynamics of aortic prostheses: comparison between stentless bioprostheses and mechanical valves. Ann Thorac Surg 2001; 72:1217-21.
15. Cohen G, Christakis GT, Joyner CD, Morgan CD, Tamariz $\mathrm{M}$, Hanayama $\mathrm{N}$ et al. Are stentless valves hemodynamically superior to stented valves? A prospective randomized trial. Ann Thorac Surg 2002; 73:767-78.

6. Braile DM, Zaiantchick M, Souza DRS. Prótese pericárdio bovino PB IMC: 11 anos em posição mitral. Arq Bras Cardiol 1992; 59:13-21.

17. Braile DM. Prótese valvular de pericárdio bovino: desenvolvimento e aplicação clínica em posição mitral [Tese de doutorado]. São Paulo: Escola Paulista de Medicina,1990.110p.

18. Braile DM. Cardioplegia isotérmica anterógrada retrógrada de baixo volume. Apostila. $2^{\mathrm{a}}$ ed. rev. ampl. São José do Rio Preto, 1997.

19. Carpentier A, Lemaigre G, Robert L, Carpentier S, Dubost C. Biological factors affecting long-term results of valvular heterografts. J Thorac Cardiovasc Surg 1969; 58:467-83.

20. Ionescu MI. Long-term durability of the pericardial valve. Z Kardiol 1986; 75(suppl 2):207-12

21. Williams RJ, Muir DF, Pathi V, MacArthur K, Berg GA Randomized controlled trial of stented and stentless aortic bioprostheses: hemodynamic performance at 3 years. Semin Thorac Cardiovasc Surg 1999;11(4 suppl 1):93-7.

22. Jin XY, Westaby S. Pericardial and porcine stentless aortic valves: are they hemodynamically different? Ann Thorac Surg 2001; 71(5 suppl):S311-4.

23. Banbury MK, Cosgrove $3^{\text {rd }}$ DM, Lytle BW, Smedira NG Sabik JF, Saunders CR. Long-term results of the CarpentierEdwards pericardial aortic valve: a 12 year follow-up. Ann Thorac Surg 1998; 66(6 suppl):S73-6.

24. Glower DD, White WD, Hatton AC, Smith LR, Young WG, Wolfe WG et al. Determinants of reoperation after 960 valve replacements with Carpentier-Edwards prostheses. J Thorac Cardiovasc Surg 1994; 107:381-93.

25. Cosgrove DM, Lytle BW, Taylor PC, Camacho MT, Stewart PM, McCarthy PM et al. The Carpentier-Edwards pericardial aortic valve: ten years results. J Thorac Cardiovasc Surg 1995; 110 (3); 651-62.

26. Vitale N, Clark SC, Ramsden A, Hasan A, Hilton CJ, Holden MP. Clinical and hemodynamic evaluation of small Perimount aortic valves in patients aged 75 years or older. Ann Thorac Surg 2003; 75:35-40. 